Article

\title{
The Use of Direct Carbon Fuel Cells in Compact Energy Systems for the Generation of Electricity, Heat and Cold
}

\author{
Robert Zarzycki *, Andrzej Kacprzak ${ }^{\mathbb{D}}$ and Zbigniew Bis
}

Department of Energy Engineering, Faculty of Infrastructure and Environment, Czestochowa University of Technology, Brzeźnicka 60a, 42-201 Częstochowa, Poland; akacprzak@is.pcz.pl (A.K.); zbis@is.pcz.czest.pl (Z.B.)

* Correspondence: zarzycki@is.pcz.czest.pl; Tel.: +48-502-049-273

Received: 15 October 2018; Accepted: 5 November 2018; Published: 7 November 2018

check for updates

\begin{abstract}
The study presents a concept and calculations concerning the operation of the direct carbon fuel cell (DCFC) with molten hydroxide electrolyte (MH-DCFC) as the basic source of electricity integrated with heat and cool air generation systems. The technology of direct carbon fuel cells assumes the direct use of a carbon fuel (such as fossil coal, carbonized biomass, graphite, coke etc.) to generate electricity with high efficiency and low impact on the environment. These cells operate by utilizing carbon fuel in the range of temperatures of 673-973 K and allow for generation of electricity with an efficiency of about $56 \%$. In order to improve the fuel conversion efficiency, the heat generated in the process of cell cooling can be used to prepare hot water, for heating during the heating season, while during the summer period, heat from cooling of the direct carbon fuel cells can be utilized in the process of cool air production (chilled air) using absorption chillers for e.g. air conditioning. This paper presents a case study and simulation calculations of the system composed of MH-DCFC that generates electricity, and runs heat exchangers and an absorption chiller, integrated with the fuel cell to generate heating and cooling for improving the efficiency of the whole system. The maximum heat and cool streams that can be obtained during the operation of the cell were also evaluated. The results obtained in the study can be helpful in the design of autonomous buildings equipped in direct carbon fuel cells as sources of electricity integrated with the systems of heat and cool generation.
\end{abstract}

Keywords: direct carbon fuel cell; cogeneration; trigeneration; absorption chillers; heating; electricity generation; energy storage

\section{Introduction}

Noticeable tendencies in the development of energy technologies are being observed in the European Union and all over the world, with their major task being not only to increase generation capacity but also to improve the efficiency of conversion of coal (which is the largest source of energy for generating electricity and the most abundant fossil fuel in the world [1,2]) combined with activities commonly termed "sustainable development" [3,4]. Coal is known as the most carbon-intensive fossil fuel and the continuing use of coal in global electrification could have implications for climate change mitigation strategies [5-8]. Nevertheless, coal will still play an important role in energy systems that support sustainable development for the foreseeable future. This is because of coal's unique combination of advantages: it is low-cost fuel, it is easy and safe to transport and store and it is available from a wide range of sources. Therefore, coal remains essential in achieving a diverse, balanced and secure energy mix. It can also meet the growing energy needs of many developing countries. On the other hand, electricity generation from coal generates several pollutants including $\mathrm{CO}_{2}$ (greenhouse gas (GHG)), $\mathrm{SO}_{\mathrm{x}}, \mathrm{NO}_{\mathrm{x}}$, particulate matter (PM) and heavy metals which are accumulated in air and 
water and lead to severe environmental and health impacts. Therefore, new innovative technologies are needed to be developed for generation of energy from coal with low pollutants emissions and high conversion efficiency.

The development of cogeneration, trigeneration or polygeneration which consists of the production of two or more energies (or other products) simultaneously is a viable option for raising the effectiveness of coal chemical energy use. Generally, these technological solutions offer many environmental and economic benefits. Moreover, among numerous modern high-performance and low-emissions energy technologies that allow for transformation of coal into electricity and heat, the most interesting are direct carbon fuel cells (DCFCs). This technology is promising and has been extensively explored recently in research and development studies [9-13]. DCFC is a power generation device converting the chemical energy of coal directly into electricity. The energy is converted through direct electrochemical oxidation of the fuel without combustion or gasification processes and without using any 'intermediate' technologies or machinery (e.g., steam turbines, thermal engines, etc.). Furthermore, during operation, DCFCs do not emit pollutants such as $\mathrm{SO}_{\mathrm{x}}, \mathrm{NO}_{\mathrm{x}}$, or PM, since the only product of the electrochemical oxidation of carbon is carbon dioxide. The basic structure of a direct carbon fuel cell is identical to any of the other fuel cells. The only difference is that the anode chamber is supplied with a solid carbonaceous fuel (e.g., hard coals, biomass-derived biochars, active carbons, carbon black, graphite, coke, etc.) that is oxidized directly at the anode surface.

Compared to other technologies the solid carbon fueled fuel cells have several unique features and advantages offering higher thermodynamic efficiency and lower emission of carbon dioxide per unit of the generated electricity. On the other hand, high-quality waste heat is produced during operation of DCFCs, which should be managed to improve fuel conversion efficiency. In recent years, research problems concerning utilization of waste heat produced by those fuel cells has become very topical. Munnings et al. [14] proposed that waste heat from solid oxide direct carbon fuel cells (SO-DCFCs) could be used for fuel (coal) drying or pyrolysis, used within a low-pressure steam turbine or for syngas production. Consequently, the DCFCs can be viewed as both a coal-based power production technology and a key enabler for production of high-value-added products. Chen et al. [15] presented and analyzed a new hybrid system which mainly consisted of a DCFC with molten carbonate as an electrolyte (MC-DCFC), a regenerator and a Carnot heat engine, with the Carnot heat engine driven by the high-quality waste heat generated in the DCFC. It was found that performance of the MC-DCFC can be greatly enhanced by using a Carnot heat engine for further power generation. Yang et al. [16] developed a new model of a hybrid system composed of a MC-DCFC and a thermophotovoltaic cell (TPVC). New model of the DCFC-TPVC hybrid system using a TPVC to utilize the waste heat from a MC-DCFC showed that maximum power output density and efficiency is higher compared to the stand-alone MH-DCFC. Furthermore, the DCFC unit can be integrated into cogeneration, trigeneration or polygeneration systems for further improvement of efficiency, which is highly beneficial for climate mitigation by achieving a higher reduction in $\mathrm{CO}_{2}$ emissions [17-20].

However, the research activities focus on solid oxide direct carbon fuel cells (SO-DCFCs) and molten carbonate direct carbon fuel cells (MC-MCFCs), but the direct carbon fuel cells with molten hydroxide electrolyte (MH-DCFC) have never been studied in terms of waste heat management and the possibility of integrating such a cell in cogeneration, trigeneration or polygeneration systems. The aim of the present paper is to present a new approach to effective recovery of waste heat generated in the MH-DCFC cell. This cell is considered a source of electricity and heat which can be used for heating, cooling and domestic hot water capacities for the building. The paper presents a case study and simulation calculations of the new cogeneration system (compact energy system-CES) composed of a $\mathrm{MH}-\mathrm{DCFC}$ that generates electricity and $\mathrm{CO}_{2}$, and heat exchangers and an absorption chiller, integrated with fuel cell, to generate heat and cool for improving the efficiency of the whole system. 


\section{MH-DCFC and Concept of Compact Energy System Overview}

In MH-DCFC, the electrochemical reaction between carbonaceous fuel and an oxidizing agent (pure oxygen or air) that produce electricity, takes place directly at the electrodes excluding the combustion or the moving machinery associated with conventional heat engines. A general overview of MH-DCFC operating principle is shown in Figure 1.

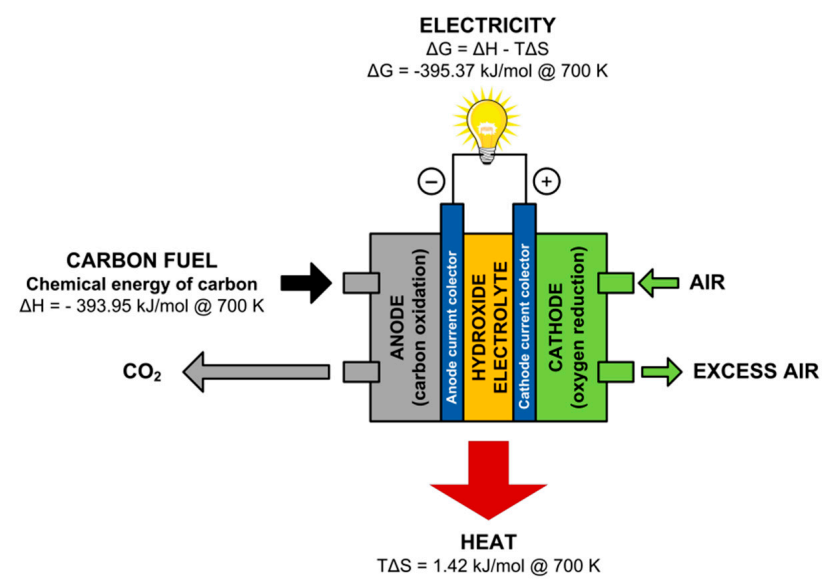

Figure 1. General scheme and basic operating principle of a MH-DCFC.

As in all fuel cells that use a hydroxide electrolyte, general cell reactions in MH-DCFC are:

Anode reaction:

$$
\mathrm{C}+4 \mathrm{OH}^{-} \rightarrow \mathrm{CO}_{2}+2 \mathrm{H}_{2} \mathrm{O}+4 \mathrm{e}^{-}
$$

Cathode reaction:

$$
4 \mathrm{e}^{-}+\mathrm{O}_{2}+2 \mathrm{H}_{2} \mathrm{O} \rightarrow 4 \mathrm{OH}^{-}
$$

Overall reaction:

$$
\mathrm{C}+\mathrm{O}_{2} \rightarrow \mathrm{CO}_{2}
$$

Consequently, the MH-DCFC converts chemical energy directly into electrical energy so that the efficiency of electrochemical conversion of fuel is not limited due to the Carnot's rule. Therefore, the efficiency of a chemical process must be evaluated differently than conventional heat engines.

\begin{tabular}{|c|c|c|c|}
\hline Efficiency Parameter & Equation & Description & Value \\
\hline Theoretical efficiency $\left(\eta_{t h}\right)$ & $\eta_{t h}=\frac{\Delta G}{\Delta H}$ & $\begin{array}{l}\Delta G-\text { Gibbs free energy change of } \\
\text { overall MH-DCFC reaction (3); } \\
\text { maximum available electrical work } \\
\left(\Delta G_{700 \mathrm{~K}}=-395.37 \mathrm{~kJ} \mathrm{~mol}^{-1}\right), \\
\Delta H \text {-enthalpy change of reaction (3); } \\
\text { total chemical energy available in the } \\
\text { fuel }\left(\Delta H_{700 \mathrm{~K}}=-393.95 \mathrm{~kJ} \mathrm{~mol}^{-1}\right) .\end{array}$ & 1.004 \\
\hline $\begin{array}{l}\text { Energy efficiency }\left(\eta_{e}\right) \text { and } \\
\text { correspondent voltage or electric } \\
\text { efficiency }\left(\eta_{v}\right)\end{array}$ & $\begin{array}{c}\eta_{e}=\frac{P_{e l}}{P_{\text {fuel, }, \text { consumed }}} \\
\eta_{v}=\frac{U}{E}\end{array}$ & $\begin{array}{l}P_{e l} \text { - electric power produced by cell }(\mathrm{J}), \\
P_{f u e l, c o n s u m e d} \text { - consumed fuel power }(\mathrm{J}), \\
U \text { - actual cell voltage }(\mathrm{V}), \\
E \text {-ideal cell voltage }(\mathrm{V}) .\end{array}$ & $\begin{array}{c}0.59 \\
\text { (theoretically } 0.64)\end{array}$ \\
\hline $\begin{array}{l}\text { Fuel utilization efficiency }\left(\eta_{f}\right) \\
\text { (also called coulombic efficiency } \\
\text { or faradaic efficiency) }\end{array}$ & $\eta_{f}=\frac{C_{\text {calc }}}{C_{\text {real }}}$ & $\begin{array}{l}C_{\text {calc }} \text {-calculated carbon consumption } \\
\text { for current generation, } \\
C_{\text {real }} \text {-actual carbon consumption. }\end{array}$ & $\begin{array}{c}0.95 \\
\text { (theoretically 1.00) }\end{array}$ \\
\hline Overall net efficiency $\left(\eta_{f_{c}}\right)$ & $\eta_{f c}=\eta_{t h} \cdot \eta_{v} \cdot \eta_{f}$ & - & $\begin{array}{c}0.56 \\
\text { (theoretically } 0.64 \text { ) }\end{array}$ \\
\hline
\end{tabular}
Efficiency of DCFCs can be defined in many ways, as shown in Table 1.

Table 1. MH-DCFC performance efficiency calculations [21]. 
It is also worth mentioning that overall net efficiency $\left(\eta_{f c}=0.56 \%\right)$ is related to electricity production in the fuel cell, so the remaining $44 \%$ is related to the heat generated by the current flow through the internal resistance of the cell. Knowing that the average electrical power of the cell was $0.23 \mathrm{~W}$, the heat generated in the cell should be $0.18 \mathrm{~W}$ [21].

The details of design, configuration and the operating mechanism of MH-DCFC, as well as the details of efficiency calculations were described in previous papers [21-25]. The idea of the CES is presented in Figure 2. Its basic element is a direct carbon fuel cell with molten hydroxide electrolyte fueled by coal, described above. Apart from MH-DCFC and the fueling system adjusted to the specifically prepared fuel (chemical composition and grain size), the CES includes: absorption chiller, $\mathrm{CO}_{2}$ cooling and compression system, heat exchangers, containers for oxygen, carbon dioxide, fuel, electrolyte, used electrolyte and system for control of fuel cell operation. The main criterion for the composition of the CES is opportunities to install them in 20' (a standard ISO container of 20 feet long) or $40^{\prime}$ (a standard ISO container of 40 feet long) rail or maritime containers. Further investigations assumed that the system will be fueled by hard coal as a main or reserve fuel (in the case of the probable lack of access to renewable fuels).

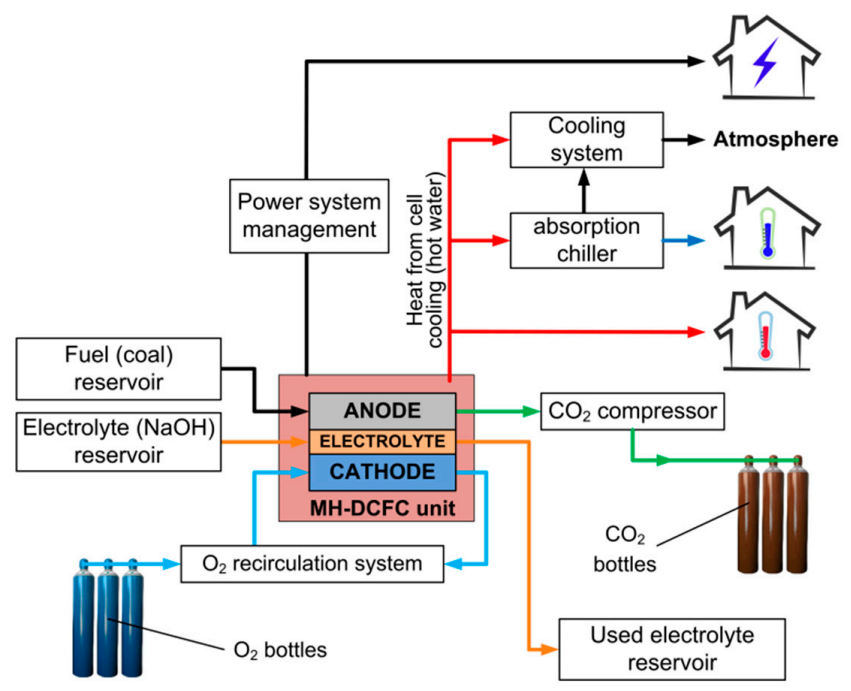

Figure 2. The concept of compact energy system (CES) using the fuel cell (MH-DCFC).

\section{MH-DCFC Module and Cogeneration System Characteristics}

The above presented data concerning MH-DCFC indicate its high electrical efficiency (56\%). Despite the high electrical efficiency of fuel cells during generation of electrical energy, it is necessary to constantly or periodically cool the cell. The heat generated during the cell's operation can be used for preparation of hot water and heating during the heating season or, using additional equipment (e.g., absorption chillers that produce chilled water) can be used to fuel air-conditioning systems.

Based on the information presented in the previous section and the design, configuration and operating mechanism of MH-DCFC described in references [21-25], the cell was rescaled to target electrical power of the $25 \mathrm{kWe}$ that allows for its commercial use while ensuring opportunities for its transport. Maritime, rail and road transport is mainly based on $20^{\prime}$ and $40^{\prime}$ shipping containers. The basic data of shipping containers are compared in Table 2 . The main parameters necessary for fuel cell scaling are presented in Table 3. 
Table 2. Basic specifications of maritime containers.

\begin{tabular}{lccc}
\hline & & $\mathbf{2 0}^{\prime}$ Container & $\mathbf{4 0}^{\prime}$ Container \\
\hline \multirow{2}{*}{ External dimensions } & length & $6.058 \mathrm{~m}$ & $12.192 \mathrm{~m}$ \\
& width & $2.438 \mathrm{~m}$ & $2.438 \mathrm{~m}$ \\
& height & $2.591 \mathrm{~m}$ & $2.591 \mathrm{~m}$ \\
\hline \multirow{2}{*}{ Interior dimensions } & length & $5.867 \mathrm{~m}$ & $12.032 \mathrm{~m}$ \\
& width & $2.352 \mathrm{~m}$ & $2.352 \mathrm{~m}$ \\
& height & $2.385 \mathrm{~m}$ & $2.385 \mathrm{~m}$ \\
\hline Internal volume & & $33.1 \mathrm{~m}^{3}$ & $67.5 \mathrm{~m}^{3}$ \\
Maximum gross weight & & $30,400 \mathrm{~kg}$ & $30,400 \mathrm{~kg}$ \\
Empty weight & & $2200 \mathrm{~kg}$ & $3800 \mathrm{~kg}$ \\
Net load & & $28,200 \mathrm{~kg}$ & $26,200 \mathrm{~kg}$ \\
\hline
\end{tabular}

Table 3. Basic specifications of a fuel cell.

\begin{tabular}{lc}
\hline \multicolumn{1}{c}{ Parameter } & Value \\
\hline Fuel cell power per electrolyte volume & $2086.3 \mathrm{~W}_{\mathrm{e}} / \mathrm{m}^{3}$ electrolyte \\
Operating temperature range & $673-973 \mathrm{~K}$ \\
Electrolyte density at temperature of $723 \mathrm{~K}$ & $1722 \mathrm{~kg} / \mathrm{m}^{3}$ \\
Electrical efficiency of fuel cell & $55.5 \%$ \\
\hline
\end{tabular}

Analysis of the data presented in Table 2 reveals that the maximal mass of fuel cell with necessary equipment and devices cannot exceed $28,200 \mathrm{~kg}$ or $26,200 \mathrm{~kg}$ depending on the container variant used.

The design of a MH-DCFC unit is shown in Figure 3. A fuel cell is composed of a casing typically made of nickel and a set of electrodes (anode and cathode-a series of nickel plates) submerged in the electrolyte. The electrode chambers are separated from each other with a porous separator made of e.g., nickel foam or porous ceramics.

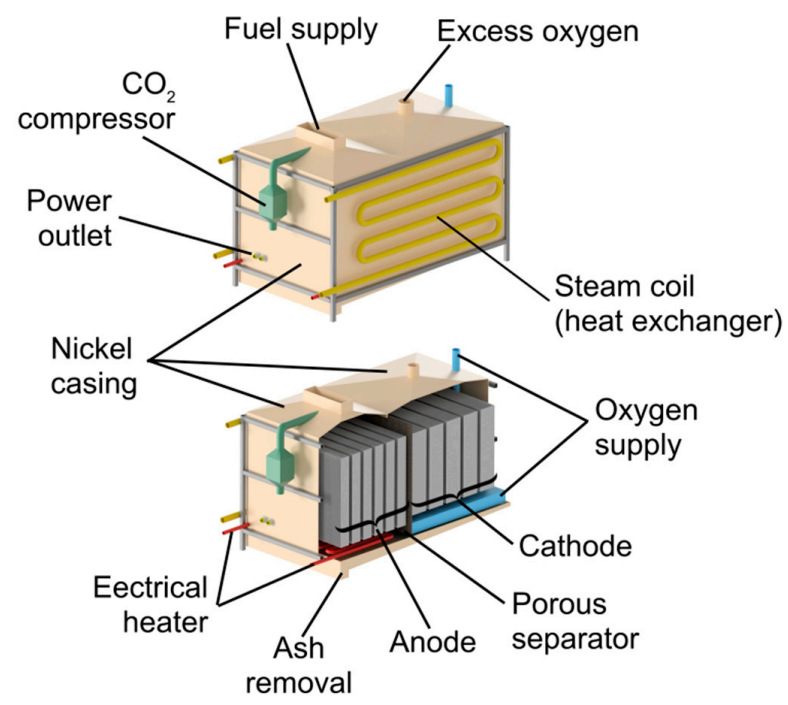

Figure 3. Design of MH-DCFC unit.

The cell is equipped in a system of continuous supply of oxygen and discharge of excess oxygen, which work together in a closed system (the $\mathrm{O}_{2}$ recirculation system is shown in Figure 4) to avoid heat losses due to continuous supply of a fresh oxidizer such as air. Operation of the cell is also possible using air instead of pure oxygen but an additional heat exchanger should be used in this option to recover the heat of excess air leaving the cell at the cathode side. The recovered heat would be used to heat the air stream supplied to the MH-DCFC. Outside the nickel casing there is a set of 
steam coil performing the role of heat exchanger that allows for heating water to the temperature of $368 \mathrm{~K}$. maximal heat power of the coil system is $200 \mathrm{~kW}$. A set of electrical heaters with power of $25 \mathrm{~kW}$ is installed in the lower part of anode chamber, with its task being electrolyte melting at the first cell activation and maintaining cell temperature at the adopted level in the case of the lack of reception of the electricity from the cell by external recipients (the electricity produced by the cell is used to maintain a certain operating temperature-standby mode). Operation of heaters allows for increasing the rate of heat accumulation in the cell through generation of heat from electrochemical processes and resistance heating of electrolyte with the heaters. Carbon dioxide generated during cell operation is collected under the anode cover and then cooled and compressed. A power outlet is mounted outside the cell casing in the form of electric terminals. For the assumed power, the necessary electrolyte volume is $12 \mathrm{~m}^{3}$, which corresponds to an electrolyte mass of 20,664 kg. The obtained values of electrolyte volume and mass allow for using the $20^{\prime}$ containers for installation of a CES. Furthermore, this container has a favorable mass to volume ratio.

Figure 4 presents the design of a cell in the $20^{\prime}$ container with all necessary installations. The system is composed of a fuel cell (MH-DCFC unit) with electrical power of $25 \mathrm{kWe}$, fuel buffer (coal reservoir), set of bottles containing $\mathrm{O}_{2}$, buffer (reservoir) for ash and used electrolyte, system for cooling and compression of $\mathrm{CO}_{2}$, containers that store liquid $\mathrm{CO}_{2}$, system for control and measurement and transforming direct current into alternating current, buffer (reservoir) with reserve of $\mathrm{NaOH}$ ('fresh' electrolyte), absorption chiller with fixtures, cooling system for the absorption chiller and emergency cooling of the cell and system of $\mathrm{O}_{2}$ recirculation in the cathode area. The cell cooling agent can be water or water vapour (steam) which is discharged from the system using pipes led outside the container. Total calculated mass of the system without fuel and electrolyte reservoirs and $\mathrm{O}_{2}$ bottles is $28,000 \mathrm{~kg}$. The weight of same fuel cell with electrolyte is $24,700 \mathrm{~kg}$.

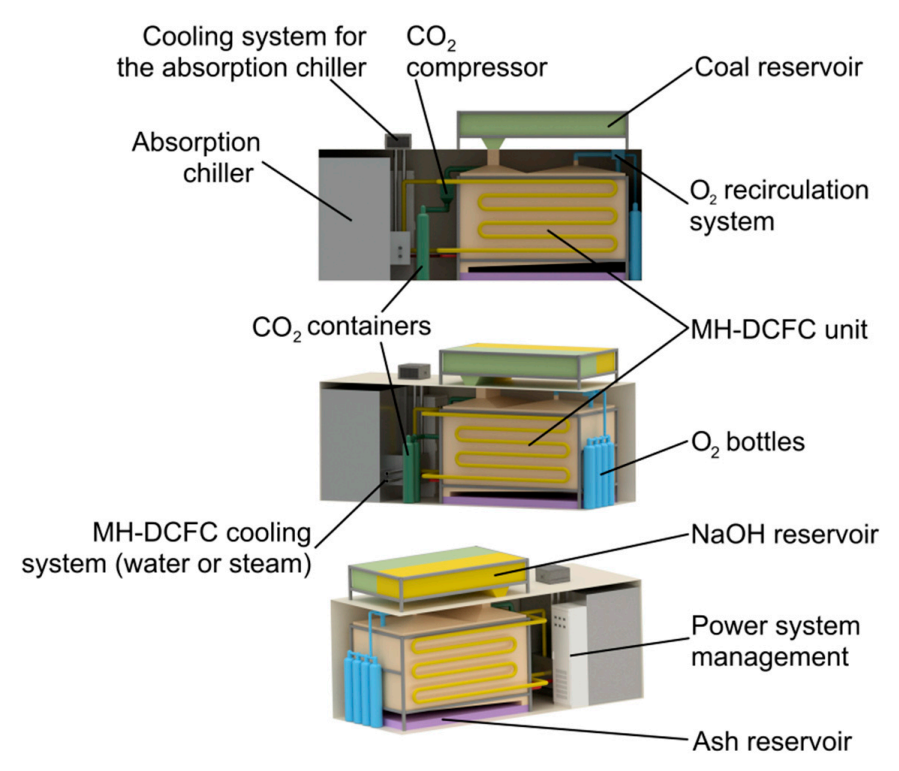

Figure 4. Organization of a MH-DCFC unit in a $20^{\prime}$ container.

The operation of the module can be divided into three stages:

- Supplying the cell module in the container to the user (electrolyte is already in liquid state and fuel cell is in standby mode)—connecting the cell module with the current infrastructure (installation for hot water, chilled water and electricity).

- Fuel cell operation: production of electricity, heat and cold to meet the user needs. Replenishment of fuel and oxygen (exchange of bottles), exchange of the buffer with ash and consumed electrolyte, reception of liquid $\mathrm{CO}_{2}$. 
- Transport of the cell to the place of electrolyte regeneration (electrolyte in the liquid state), inspection and repairing the cell, electrolyte regeneration.

The fuel cell module (unit) presented in Figure 3 can produce a maximal electrical power of $25 \mathrm{~kW}_{\mathrm{e}}$. Electricity generation efficiency in the cell was assumed to be $55.5 \%$. With maximal electrical power, heat flux generated in the electrochemical processes amounts to $20 \mathrm{~kW}_{\mathrm{th}}$, which corresponds to the thermal power of the cell of $20 \mathrm{~kW}_{\mathrm{th}}$.

The minimum operational temperature is $673 \mathrm{~K}$ and is limited by the electrolyte melting temperature $(589 \mathrm{~K})$. Maximum cell operating temperature of $973 \mathrm{~K}$ is limited by the mechanical strength of the cell structure and the increase in cell components corrosion rate.

The Compact Energy System presented in Figure 2 can be operated with the following variants:

(A) Generation of electricity $\left(\mathrm{P}_{\mathrm{e}}=25 \mathrm{~kW}\right)$ and heat $\left(\mathrm{P}_{\mathrm{th}}=20 \mathrm{~kW}\right.$ th $)$ with ratio $\mathrm{P}_{\mathrm{e}} / \mathrm{P}_{\text {th }}$ of 1.25 ;

(B) Generation of electricity and storage of heat in molten electrolyte;

(C) Generation of electricity and cold using an absorption chiller;

With electrical capacity of the fuel cell of $25 \mathrm{~kW}_{\mathrm{e}}$ and an efficiency of $55.5 \%$, the heating power of the cell is $20 \mathrm{~kW}_{\mathrm{th}}$. In the case of cell operation with the above power specifications, the cell (electrolyte) temperature will not be changed.

Heat and electricity demand is mostly varied, with the highest demand for electricity observed over the day, whereas in the winter season, the highest demand for heat occurs at night.

The proposed design of the cogeneration system of the cell allows for the separated use of electricity and heat. This is possible due to accumulation of heat in the molten electrolyte and structural components of the cell. Mass of electrolyte contained in the cell is 20,664 kg, whereas specific heat of molten electrolyte in the range of temperatures from $592 \mathrm{~K}$ to $973 \mathrm{~K}$ can be described by the following equation [26]:

$$
c_{p}=2.199-1.46 \cdot 10^{-4} \cdot t\left[\mathrm{~kJ} \mathrm{~kg}^{-1} \mathrm{~K}^{-1}\right]
$$

All cell components which are in contact with molten electrolyte are made of nickel, with its specific heat ranging from $100 \mathrm{~K}$ to $1500 \mathrm{~K}$, as presented in Table 4.

Table 4. Values of specific heat for nickel [27].

\begin{tabular}{cc}
\hline $\boldsymbol{t}(\mathbf{K})$ & $c\left(\mathbf{J ~ k g}^{-\mathbf{1}} \mathbf{K}^{-\mathbf{1}}\right)$ \\
\hline 100 & 232 \\
200 & 383 \\
400 & 485 \\
600 & 592 \\
800 & 530 \\
1000 & 562 \\
1200 & 594 \\
1500 & 616 \\
\hline
\end{tabular}

Based on the design data of the cell model, a mathematical model of cell operation in the range of temperatures of $673-973 \mathrm{~K}$ was developed using the $\mathrm{C}++$ software.

\section{Results}

\subsection{Variant $A$}

With nominal electrical and heat power and other operating conditions for which ratio of electricity to heat generation is $\mathrm{P}_{\mathrm{e}} / \mathrm{P}_{\text {th }}=1.25$ (for cell efficiency of $55.5 \%$ ), electrolyte temperature remains unchanged. 


\subsection{Variant $B$}

In the case of electricity production without heat reception from the cell, the heat generated from the cell in electrochemical processes leads to an increase of electrolyte temperature. The safe range of cell operating temperatures adopted is $673-973 \mathrm{~K}$ and at temperature of $673 \mathrm{~K}$, the amount of heat collected in the cell equals zero.

Figure 5 presents the amount of heat collected in the cell. The highest amount of heat is collected in the electrolyte $\left(\mathrm{Q}_{\mathrm{NaOH}}\right)$ due to its mass and specific heat (mean specific heat of the electrolyte for the range of $673-973 \mathrm{~K}$ is $2.118 \mathrm{~kJ} \mathrm{~kg}-1 \cdot \mathrm{K}^{-1}$ ). The amount of heat collected in structural components of the cell $\left(\mathrm{Q}_{\mathrm{Ni}}\right)$ is over 19 times lower, which results from their lower mass and lower specific heat (mean specific heat of nickel for the range of $673-973 \mathrm{~K}$ is $0.546 \mathrm{~kJ} \mathrm{~kg}^{-1} \cdot \mathrm{K}^{-1}$ ). The amount of heat in the cell for the range of $673-973 \mathrm{~K}$ is $13.287 \mathrm{GJ}$.

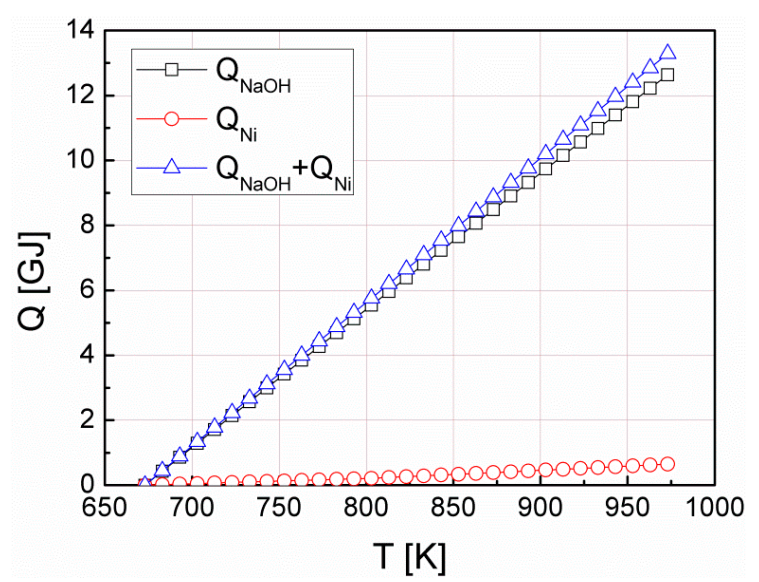

Figure 5. Heat collected in the electrolyte $\left(\mathrm{Q}_{\mathrm{NaOH}}\right)$, structural components of the cell $\left(\mathrm{Q}_{\mathrm{Ni}}\right)$ and total heat stored in the cell $\left(\mathrm{Q}_{\mathrm{NaOH}+\mathrm{QNi}}\right)$.

Maximum operating time of the cell with power of $25 \mathrm{~kW}$, starting from cell temperature of $673 \mathrm{~K}$ to $973 \mathrm{~K}$ is $184 \mathrm{~h}$. It allows for accumulation of $13.287 \mathrm{GJ}$ of heat. Figure 6 presents the characteristics of the temperature increase during heat accumulation in the cell with the electrical power of the cell set at $25 \mathrm{~kW}_{\mathrm{e}}$.

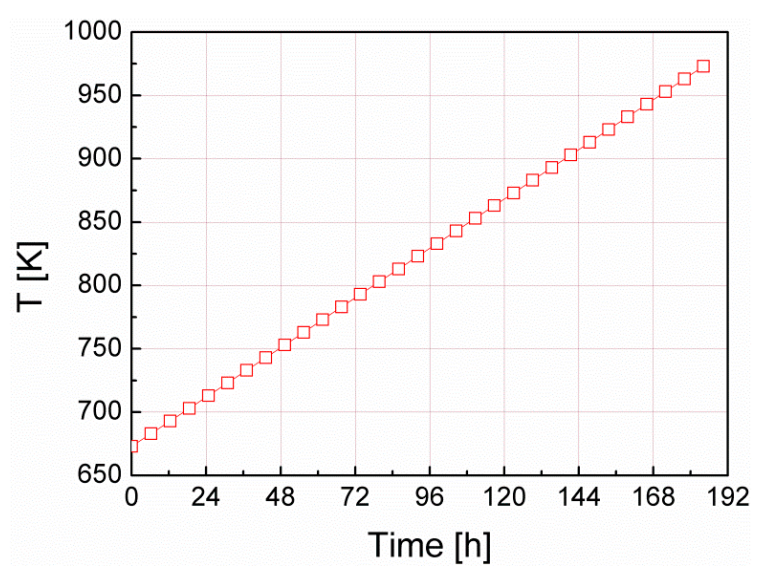

Figure 6. Fuel cell temperatures vs. time for electrical power of fuel cell of $25 \mathrm{~kW}_{\mathrm{e}}$ (without heat reception: storing heat in the cell).

If the cell reaches the temperature of $973 \mathrm{~K}$, it is necessary to switch it off or transfer the heat in an amount that ensures maintaining the temperature of the cell at a constant level. 
Heat accumulated in the cell can be used for heating, production of hot water or the purposes of powering an absorption chiller. The cell design allows for collecting heat from the fuel cell at a maximal power of $200 \mathrm{~kW}$. This allows for discharging the idle cell (from $673 \mathrm{~K}$ to $973 \mathrm{~K}$ ) in $18 \mathrm{~h}$ and $27 \mathrm{~min}$, whereas if the cell is operates at its nominal power of $25 \mathrm{~kW}_{\mathrm{e}}$, the time of cell discharge is $20 \mathrm{~h}$ and $30 \mathrm{~min}$. After this time, the cell temperature reaches $673 \mathrm{~K}$. If the cell temperature declines below $673 \mathrm{~K}$, the automatic control system starts the idle cell at nominal power and the heat generated during electrochemical processes increases electrolyte temperature. The electrical heaters present in the cell with power of $25 \mathrm{~kW}$ ensure the reception of electricity. In this case, it is possible to quickly replenish the accumulated heat with power of $45 \mathrm{~kW}_{\mathrm{th}}$. If the heat is expected to be used at power lower than the peak value of $200 \mathrm{~kW}$, the time of battery heat discharge is accordingly longer.

\subsection{Variant $C$}

Apart from supplying electricity and heat, the fuel cell also allows for generation of cold using absorption chiller technology. Figure 7 presents an absorption chiller chosen for the installation with maximal cooling power of $45 \mathrm{~kW}$.

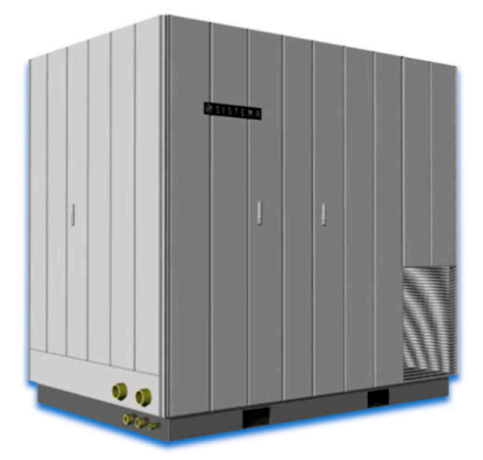

Figure 7. Absorption chiller module [28].

In the case of the analyzed co-generation system (CES), the absorption chiller was powered with hot water. Table 5 presents basic specifications of an absorption chiller. The energy efficiency rating is 0.75 . This means that for the electrical power of the cell of $25 \mathrm{~kW}_{\mathrm{e}}$ (thermal power of the cell of $20 \mathrm{~kW}_{\text {th }}$ ) in the steady state (unchanged electrolyte temperature), cold can be generated at $15 \mathrm{~kW}$. Considering heat accumulation in the cell and production of cold for only $8 \mathrm{~h}$, it is possible to install absorption chillers with cooling power of $45 \mathrm{~kW}$.

Table 5. Basic specifications of an absorption chiller [28].

\begin{tabular}{|c|c|c|}
\hline \multicolumn{3}{|c|}{ Absorption Chiller SYBCTDH70 (45)85/95 } \\
\hline Max. cooling capacity with supply of water $\left(95^{\circ} \mathrm{C}\right)$ & $\mathrm{kW}$ & 45 \\
\hline \multicolumn{3}{|c|}{ Chilled Water } \\
\hline Delivery water temperature & ${ }^{\circ} \mathrm{C}$ & 7 \\
\hline Return water temperature & ${ }^{\circ} \mathrm{C}$ & 11.5 \\
\hline Flow rate & $\mathrm{m}^{3} / \mathrm{h}$ & 8.6 \\
\hline Useful heat & $\mathrm{mH}_{2} \mathrm{O}$ & 11 \\
\hline \multicolumn{3}{|c|}{ Hot Water Supply } \\
\hline Inlet temperature & ${ }^{\circ} \mathrm{C}$ & 95 \\
\hline Outlet temperature & ${ }^{\circ} \mathrm{C}$ & 85 \\
\hline Supply water & $\mathrm{m}^{3} / \mathrm{h}$ & 5.37 \\
\hline Available inlet heat & $\mathrm{kW}$ & 60 \\
\hline \multicolumn{3}{|c|}{ General Data } \\
\hline Weight & $\mathrm{kg}$ & 2.100 \\
\hline Dimensions $(\mathrm{L} \times \mathrm{P} \times \mathrm{H})$ & $\mathrm{m}$ & $2.25 \times 1.61 \times 2.23$ \\
\hline
\end{tabular}




\section{Conclusions}

The proposed design of a cogeneration system with a direct carbon fuel cell allows for using coal as a source for generation of electricity and heat or cold. The electrolyte contained in the cell and its structural components represent a heat storage area capable of collecting an amount of heat of 13.287 GJ. This heating capacity allows for its operation at nominal electrical power for $184 \mathrm{~h}$ without receiving heat from the cell. The cell design allows for collecting heat from the fuel cell at a maximal power of $200 \mathrm{~kW}$. With the amount of heat collected in the cell, the maximum time of cell discharge with the maximum power of $200 \mathrm{~kW}$ is $18 \mathrm{~h}$ and $27 \mathrm{~min}$ if electricity is not generated. If the cell is operated at nominal power $\left(25 \mathrm{~kW}_{\mathrm{e}}\right)$, the heat accumulated in the cell allows for using the cell at $200 \mathrm{~kW}$ for $20 \mathrm{~h}$ and $30 \mathrm{~min}$. The heat accumulated in the cell can be used to power an absorption chiller with a cooling capacity of $45 \mathrm{~kW}$. The automatic control system allows for control of the fuel cell over asafe range of temperatures. If the temperature falls below the electrolyte temperature of $673 \mathrm{~K}$, the system starts the fuel cell to power the heaters installed in the lower part of the cell anode chamber, which helps to quickly increase the cell temperature and accumulate the required amount of heat.

The proposed solution can be used to supply electricity to detached houses or multi-family buildings and also as a source of heat or cold. The proposed system can represent a source of electricity used to charge electrical vehicles at night, which will beneficially impact on the operation of the cell, thus allowing for accumulation of heat for the purposes of powering of the absorption chiller over the day. The system of cooling, compression and condensation of $\mathrm{CO}_{2}$ allows for $\mathrm{CO}_{2}$ storage. Consequently, the installation can be considered as a zero-emission system if $\mathrm{CO}_{2}$ stored is reused as a substrate, e.g., in industrial processes.

Author Contributions: Conceptualization, R.Z. and A.K.; Methodology, R.Z. and A.K.; Software, R.Z.; Validation, Z.B., R.Z. and A.K.; Formal Analysis, R.Z. and A.K.; Investigation, R.Z. and A.K.; Data Curation, R.Z. and A.K.; Writing-Original Draft Preparation, R.Z. and A.K.; Writing-Review \& Editing, Z.B. and A.K.; Visualization, A.K. and R.Z.; Supervision, Z.B.; Project Administration, R.Z. and Z.B.; Funding Acquisition, Z.B.

Funding: This research was partially funded by the Ministry of Science and Higher Education of Poland grant number [BS/PB-404-301/11].

Conflicts of Interest: The authors declare no conflict of interest.

\section{References}

1. International Energy Agency. World Energy Outlook 2017; International Energy Agency: Paris, France, November 2017.

2. World Energy Council. World Energy Resources; World Energy Council: London, UK, 2016.

3. Medunić, G.; Mondol, D.; Rađenović, A.; Nazir, S. Review of the latest research on coal, environment, and clean technologies. Rudarsko-Geološko-NaftniZbornik 2018, 33, 13-21. [CrossRef]

4. Yue, G.; Li, S. (Eds.) Clean Coal Technology and Sustainable Development: Proceedings of the 8th International Symposium on Coal Combustion; Springer: Berlin, Germany, 2016.

5. Chowdhury, M.M.R. Essence of international environmental law to address the effects of climate change. In Emerging Economic Models for Global Sustainability and Social Development; Christiansen, B., Sysoeva, I., Udovikina, A., Ketova, A., Eds.; IGI Global: Hershey, PA, USA, 2018; Chapter 12; pp. 220-236.

6. Akpan, U.F.; Akpan, G.E. The contribution of energy consumption to climate change: A feasible policy direction. Int. J. Energy Econ. Policy 2011, 2, 21-33.

7. Energy Climate and Change; World Energy Outlook Special Report; IEA: Paris, France, 2015.

8. Lefèvre, N. Energy Security and Climate Policy: Assessing Interactions; OECD/IEA: Paris, France, 2007.

9. Badwall, S.; Giddey, S. The holy grail of carbon combustion-The direct carbon fuel cell technology. Mater. Forum 2010, 34, 181-185.

10. Giddey, S.; Badwal, S.P.S.; Kulkarni, A.; Munnings, C. A comprehensive review of direct carbon fuel cell technology. Prog. Energy Combust. Sci. 2012, 38, 360-399. [CrossRef]

11. Kacprzak, A. Hydroxide electrolyte direct carbon fuel cells-Technology review. Int. J. Energy Res. 2018, 1-21. [CrossRef] 
12. Desclaux, P.; Rzepka, M.; Stimming, U.; Hempelmann, R. Actual state of technology in direct carbon fuel cells. Z. Phys. Chem. 2013, 227, 627-649. [CrossRef]

13. Deleebeeck, L.; Hansen, K.K. Hybrid direct carbon fuel cells and their reaction mechanisms-A review. J. Solid State Electr. 2014, 18, 861-882. [CrossRef]

14. Munnings, C.; Giddey, S.; Badwal, S. Direct carbon fuel cells: An ultra-low emission tech for power generation. Cornerstone 2014, 2, 56-60.

15. Chen, L.; Zhang, H.; Gao, S.; Yan, H. An available method utilizing the waste heat in a direct carbon fuel cell. Int. J. Electrochem. Sci. 2014, 9, 5788-5802.

16. Yang, Z.; Peng, W.; Liao, T.; Zhao, Y.; Lin, G.; Chen, J. An efficient method exploiting the waste heat from a direct carbon fuel cell by means of a thermophotovoltaic cell. Energy Convers. Manag. 2017, 149, 424-431. [CrossRef]

17. Parise, J.A.; Vargas, J.V.; Marques, R.P. Fuel cells and cogeneration. J. Fuel Cell Sci. Technol. 2008, 5, 034002. [CrossRef]

18. Malico, I.; Carvalhinho, A.P.; Tenreiro, J. Design of a trigeneration system using a high-temperature fuel cell. Int. J. Energy Res. 2009, 33, 144-151. [CrossRef]

19. Samavati, M.; Raza, R.; Zhu, B. Design of a 5-kW advanced fuel cell polygeneration system. Wiley Interdiscip. Rev. Energy Environ. 2012, 1, 173-180. [CrossRef]

20. Adams, T.A., II; Barton, P.I. Combining coal gasification, natural gas reforming, and solid oxide fuel cells for efficient polygeneration with $\mathrm{CO}_{2}$ capture and sequestration. Fuel Process. Technol. 2011, 92, 2105-2115. [CrossRef]

21. Kacprzak, A.; Kobyłecki, R.; Włodarczyk, R.; Bis, Z. Efficiency of non-optimized direct carbon fuel cell with molten alkaline electrolyte fueled by carbonized biomass. J. Power Sources 2016, 321, 233-240. [CrossRef]

22. Kacprzak, A.; Włodarczyk, R.; Kobyłecki, R.; Ścisłowska, M.; Bis, Z. Fuel cell as part of clean technologies. In Environmental Engineering IV; Pawłowski, A., Dudzińska, M.R., Pawłowski, L., Eds.; CRC Press, Taylor \& Francis Group: London, UK, 2013; pp. 443-450. ISBN 978-0-415-64338-2.

23. Kacprzak, A.; Kobyłecki, R.; Bis, Z. Influence of temperature and composition of $\mathrm{NaOH}-\mathrm{KOH}$ and $\mathrm{NaOH}-\mathrm{LiOH}$ electrolytes on the performance of a direct carbon fuel cell. J. Power Sources 2013, 239, 409-414. [CrossRef]

24. Kacprzak, A.; Kobyłecki, R.; Włodarczyk, R.; Bis, Z. The effect of fuel type on the performance of a direct carbon fuel cell with molten alkaline electrolyte. J. Power Sources 2014, 255, 179-186. [CrossRef]

25. Kacprzak, A.; Kobyłecki, R.; Bis, Z. The effects of operating conditions on the performance of a direct carbon fuel cell. Arch. Thermodyn. 2013, 34, 187-197. [CrossRef]

26. Douglas, T.B.; Dever, J.L. Anhydrous sodium hydroxide: The heat content from 0 degrees to 700 degrees $C$, the transition temperature, and the melting point. J. Res. Natl. Bur. Stand. 1954, 53, 2519. [CrossRef]

27. Incropera, F.P.; DeWitt, D.P.; Bergman, T.L.; Lavine, A.S. Fundamentals of Heat and Mass Transfer, 6th ed.; John Wiley \& Sons, Inc.: Hoboken, NJ, USA, 2007.

28. Systema Product Catalog: Package and Skid, Absorption Systems. Available online: https://www. systemaspa.si/images/pdf/Katalog_cooling_EN.pdf (accessed on 15 April 2018).

(c) 2018 by the authors. Licensee MDPI, Basel, Switzerland. This article is an open access article distributed under the terms and conditions of the Creative Commons Attribution (CC BY) license (http://creativecommons.org/licenses/by/4.0/). 